\title{
Editorial: Towards sustainable development practices in geoenvironmental engineering
}

\author{
Abdel-Mohsen O. Mohamed \\ Professor of Geotechnical and Geoenvironmental Engineering, and the \\ Associate Provost and Chief Academic Officer, Zayed University, \\ Abu Dhabi, UAE
}

As we know, solutions to complex problems confronted by the environmental restoration industry are currently handled by the geoenvironmental engineering profession; consisting of geotechnical, environmental and chemical engineers, chemists, geologists, microbiologists, and soil scientists. These professionals employ a synergy of information developed in a variety of disciplines to solve these challenging problems. In seeking solutions to restore the degraded environment, we need to consider the problem from a holistic view point that integrates ecology, economy and social objectives to reach the overall sustainable solution (Mohamed and Antia, 1998). In doing so, one would apply environmental soundness and political acceptability to the proposed solutions. An imbalance between the three main components (ecology, economy and social aspects) due to a failure in any one of them will likely result in a failure to achieve sustainable development.

Technology plays an important role in sustainable development because it is one of the most significant ways in which we interact with our environment. To proceed towards sustainability, we have to be deliberate and thoughtful in our use of technology. We need to develop and use technologies with sustainability in mind. Sustainable technologies are practical solutions to achieve economic development and human satisfaction in harmony with the environment. Technologies serve to contribute, support or advance sustainable development by reducing risk, enhance costeffectiveness, improve process efficiency, and create processes, products or services that are environmentally beneficial or benign, while benefiting humans (National Science and Technology Council, 1994). To qualify as sustainable technologies, solutions must satisfy a number of characteristics such as minimise use of nonrenewable energy and natural resources; satisfy human needs and aspirations with sensitivity to cultural context; and minimise the negative impact on the earth's ecosystem (Mohamed and Elgamal, 2010).

To achieve sustainability for society as a whole, and for the restoration industry in particular, intelligent decision making is required that includes full consideration and knowledge of the basic properties and behaviour of the land environment, trade-offs, and impacts associated with each alternative available as a viable solution option. Sustainability is a desirable state to strive towards, but the journey is not easy.
This issue of Environmental Geotechnics presents four full papers and two discussion papers. The first paper by Thakur (2015) evaluates the effect of storage time on the properties and behaviour of fine-grained soils. The importance of such a topic stems from the mere fact that a long storage time could significantly alter the pore water chemistry of the fine-grained soil samples, not only reducing the accuracy of the test results but also contributing negatively by increasing uncertainty in the basic soil parameters that are used as design values in proposed analytical solutions. Viable solutions to this problem could be determined with the help of the environmental geotechnics profession, where several testing methodologies and procedures are presented to help understand the dynamic changes in the physicochemical properties of soils overtime (Mohamed, 2006; Mohamed and Antia, 1998; Santamarina et al., 2001; Yong and Mohamed, 1992).

The second paper (Abuel-Naga et al., 2015), discusses the changes of the thermo-hydro-mechanical properties and behaviour of saturated clays due to external heat fluxes. Moreover, a conceptual understanding of the potential effect of temperature change on the soil-structure interaction was proposed. Understanding the changes of theses material properties is the key to proper design of heat exchangers for sustainable energy of buildings, barrier systems for disposal of low-level radioactive waste (Yong et al., 1997), and thermal remediation of polluted grounds.

The third paper (Azad et al., 2015), discusses the changes of the hydraulic conductivity due to electromagnetic wave application. The magnitude of the alteration of the hydraulic conductivity may not be large enough for field practical application. However, the study itself is important in the sense that it can help understand unknown aspects of soil-water interactions during the flow of electromagnetic waves in soils, especially when one uses electrokinetic technology to consolidate soft soils; electrochemical remediation to treat contaminated grounds (Mohamed, 1997; Mohamed and Antia, 1998); and the geophysical techniques to extract basic soil properties for design (Mohamed and Antia, 1998).

The fourth paper (Laefer and Farrell, 2015) differs from the main theme of the previous papers, where material properties and behaviour were the main focus. This paper focuses the attention of the readers to the reuse of materials, which is one of the corner stones 
of sustainable development. It proposes a multi-level method for engineers to conduct a pre-construction viability assessment for the reuse of existing foundation in congested urban areas. The method addresses socio-economic drivers and technical requirements to promote future reuse where current reuse is not viable. Some of the technical considerations for foundation reuse are foundation reliability, compatibility, site constraints and site surroundings. It is important to point out that scalability and robustness of the method must be further tested.

The first discussion paper, by Trivedi et al. (2015), differs from the main theme of the previous papers. This discussion paper proposes a more general theoretical equation for three-dimensional drainage system when the soil is stratified in the three dimensions. This in turn will introduce the engineering profession to explore deformations and velocity fields of consolidating clayey gouge amid permeating rock masses for varied and non-coaxial deformations. The impact of such analysis can be seen in analysing stability of soil masses, where the stress and strain tensors are not co-axils and the nonassociated flow rules are to be considered (Yong and Mohamed, 1984, 1988a, 1988b).

The second discussion paper, by Vardon et al. (2015), deals with the issue of incorporating climate change in geotechnical design, which is rapidly gaining importance in engineering practice. The discussion focuses attention on the impact of climate changes on soil covers, which are integral to landfills and mining waste management systems, and adds to the range of engineering areas that need to be considered. Attention should also be given to soil covers that rely on permafrost since it will be vulnerable to climate change (Mohamed et al., 1993, 1996, 1997). Therefore, to have sustainable design practices, climate effects should be considered at the design stage.

I hope you find these papers simulating and informative.

\section{REFERENCES}

Abuel-Naga H, Raouf MIN, Raouf AMI and Nasser AG (2015)

Energy piles: current state of knowledge and design challenges. Environmental Geotechnics 2(4): 195-210, http:// dx.doi.org/10.1680/envgeo.13.00019.

Azad S, Farid A and Browning J (2015) Effect of electomagnetic stimulation on hydraulic conductivity. Environmental Geotechnics 2(4): 211-223, http://dx.doi.org/10.1680/ envgeo.13.00027.

Laefer DF and Farrell K-A (2015) A hybrid method for foundation reuse revaluation. Environmental Geotechnics 2(4): 224-236, http://dx.doi.org/10.1680/envgeo.13.00034.

Mohamed AMO (1997) Remediation of heavy metal contaminated soils via integrated electro-chemical processes. Waste Management 16(8): 741-747.

Mohamed AMO (2006) Principles and Applications of Time Domain Electrometry in Geoenvironmental Engineering. Taylor and Francis, London, UK.
Mohamed AMO and Antia HE (1998) Geoenvironmental Engineering. Elsevier, Amsterdam, the Netherlands.

Mohamed AMO and Elgamal M (2010) Sulfur Concrete for the Construction Industry: A Sustainable Development Approach. J. Ross Publishing Inc., Plantation, FL, USA.

Mohamed AMO, Shooshpasha I and Yong RN (1996) Boundary layer transport of metal ions in frozen soil. International Journal for Numerical and Analytical Methods in Geomechanics 20: 693-713.

Mohamed AMO, Shooshpasha I and Yong RN (1997) Diffusion of metal ions in frozen capillary barriers. Engineering Geology 47: $1-15$.

Mohamed AMO, Yong RN, Caporuscio F, Yanful EK and Bienvenu L (1993) Chemical interaction and cyclic freeze-thaw effects on the integrity of the soil cover for the Waite Amulet Tailings. International Journal of Environmental Issues in Minerals and Energy Industry 2(3): 121-128.

National Science and Technology Council (1994) Technology for a Sustainable Future: Framework for Action. Office of Science and Technology Policy, Washington, DC, USA.

Santamarina JC, Klein KA and Fam MA (2001) Solis and Waves. John Wiley \& Sons, New York, NY, USA.

Thakur V (2015) Can we assess the effect of storage time on fine-grained soil samples? Environmental Geotechnics 2(4): 191-194, http://dx.doi.org/10.1680/envgeo.13.00090.

Trivedi A, Banik T and Sukumar T et al. (2014) Discussion: Consolidation of clayey gouge amid permeating rock masses. Environmental Geotechnics 2(4): 237-248, http://dx.doi. org/10.1680/envgeo.14.00038.

Vardon PJ, Bashir R and Sharma J (2014) Discussion: Climatic influence on geotechnical infrastructure: a review. Environmental Geotechnics 2(4): 249-252, http://dx.doi. org/10.1680/envgeo.14.00049.

Yong RN and Mohamed AMO (1992) A study of particle interaction energies in wetting of unsaturated expansive clays. Canadian Geotechnical Journal 29(6): 1060-1070.

Yong RN and Mohamed AMO (1984) Experimental study on yielding and failure of an anisotropic clay. International Journal of Mechanics of Materials 3(4): 301-310.

Yong RN and Mohamed AMO (1988a) Development of a non-associated flow rule for anisotropic clays. Journal of Engineering Mechanics, ASCE 114(3): 404-420

Yong RN and Mohamed AMO (1988b) Performance prediction of anisotropic clays under loading. Journal of Engineering Mechanics, ASCE 114(3): 421-431.

Yong RN, Mohamed AMO, Shooshpasha I and Onofrei C (1997) Hydro-thermal performance of unsaturated bentonite-sand buffer material. Engineering Geology 47: 351-365. 